Ivana Tasić

Predškolska ustanova „11. april”,

Novi Beograd

Slađana Raspopović

Predškolska ustanova „Poletarac”,

Batočina

tasicivana@gmail.com
UDK: 364.2-053.2/.6-056.26/.3

Pregledni rad

Primljen: 26. 09. 2021.

Korigovan: 10. 12. 2021.

Prihvaćen: 20. 12. 2021.

DOI: https://doi.org/10.53406/kd.v9i2.14

\title{
INKLUZIVNO OBRAZOVANJE DECE PREDŠKOLSKOG UZRASTA SA SMETNJAMA U RAZVOJU PO „GODINAMA UZLETA"
}

Sažetak: Osnove programa predškolskog vaspitanja i obrazovanja „Godine uzleta" određene su prema strukturnim elementima i zahtevima savremenih programa $i$ kurikuluma, a potom je teorijsko-vrednosna koncepcija iz koje proizilazi cilj sagledana u odnosu na dete sa smetnjama u razvoju. Sagledano je kako podržati dobrobit deteta sa smetnjama u razvoju kroz odnose i delovanje u igri, životno-praktičnim situacijama i planiranim situacijama učenja, kao i u odnosu na kontekst vrtića u kome se razvija inkluzivna praksa. Delovanje vaspitača, organizacija fizičkog prostora i strategije (principi, početno planiranje, zajedničko razvijanje programa, praćenje, vrednovanje i dokumentovanje) sagledani su u odnosu na inkluzivnu praksu. Data su zakonska uputstva za ostvarivanje prava na IOP, njegovu realizaciju i vrednovanje.

Ključne reči: inkluzivna praksa, dete sa smetnjama u razvoju, „Godine uzleta”. 


\section{Uvod}

Dete sa smetnjama u razvoju ima pravo da bude deo jedinstvenog sistema obrazovanja i vaspitanja, čiji je sastavni deo predškolska ustanova. Deca će kroz uključivanje u vrtić zajedno sa svojim vršnjacima i drugim odraslima imati čitav niz mogućnosti da aktivno učestvuju, da se igraju, da budu u podsticajnoj sredini i u situacijama koje podržavaju razvoj. Postavlja se pitanje od čega poći prilikom organizovanja vaspitno-obrazovnog rada kako bi se deca sa smetnjama uključila. $\mathrm{Na}$ koji način se individualizacija planira i ostvaruje? Nova programska koncepcija predstavlja savremeni pristup učenju i razvoju u ranom detinjstvu i zasniva se na veri u kapacitete dece da aktivno učestvuju u svom učenju i razvoju, te na značaju igre i zajedničkog učešća dece i odraslih. Jedan od opštih ciljeva „Godina uzleta” jeste da sva deca imaju jednake mogućnosti za učenje i razvoj kroz podršku njihovoj dobrobiti. Vaspitači organizuju vaspitno-obrazovni rad prateći smernice iz Osnova programa predškolskog vaspitanja i obrazovanja „Godine uzleta” ( $\mathrm{u}$ daljem tekstu „Godine uzleta”). U ovom radu prikazane su preporuke za rad sa decom sa smetnjama u razvoju i invaliditetom u predškolskim ustanovama po „Godinama uzleta”.

\section{Teorijske osnove programa}

Program se u svom najširem značenju odnosi na svaki propis i preporuku na osnovu kojih se organizuje rad u predškolskim ustanovama, a kurikulum je proces koji zavisi od društvenih zbivanja i odnosa - atmosfere u kojoj se učenje odvija. Osamdesetih godina 20 . veka program je sadržao ciljeve, zadatke, jedinice aktivnosti, oblike, metode rada i sredstva, dok je kurikulum sadržao pretpostavke o onima koji uče i društvu, ciljeve i zadatke, sadržaje, metode i oblike rada, vaspitno-obrazovna iskustva, aktivnosti dece, interakciju između dece i vaspitača, vaspitno-obrazovne metode, organizaciju vaspitno-obrazovnog rada, vreme predviđeno za to, sredstva i evaluaciju (Klemenović, 2009). Krajem osamdesetih i početkom devedesetih godina došlo je do promene u kreiranju kurikuluma, pri čemu sve značajniju ulogu dobijaju ustanove i vaspitači. Usmereni su na dete, na proces učenja, uvažavanje individualnih razlika, sa široko datim područjima aktivnosti (Klemenović, 2009) - nedovršenim, otvorenim, razvojnim, prilagodljivim svim učesnicima, kao i konkretnim uslovima u kojima će se razvijati (Kamenov, 2008). Iako su programi orijentisani ka decentralizaciji, ipak postoji nacionalni okvir koji je dat u okviru Osnova programa (Klemenović, 2009), koje su jezgro kurikuluma razradili tako da omogućava prilagođavanje individualnim karakteristikama svakog deteta, vrtiću i vaspitaču (Kamenov, 2008).

U literaturi se pronalaze klasifikacije predškolskih programa (u daljem tekstu PP) po različitim kriterijumima. Na osnovu kombinacije aspekata dečjeg razvoja, razlikuju se: 1) maturacijsko-socijalizacijski PP - usmereni na dečju nezavisnost, spontanost i inicijativnost, u kojima je navedeno samo ono što ne treba da se radi, što onemogućava planski i sistemski vaspitno-obrazovni rad, a što dovodi u pitanje njegovu efikasnost; 2) kognitivno-akademski PP - usmereni na sticanje 
znanja, zasnovani na shvatanjima da se ponašanje oblikuje iskustvima i znanjima koja se stiču u školi i da dete treba da sluša i prilagođava se, što onemogućava integraciju iskustva, prilagođavanje individualnim karakteristikama dece, specifičnim uslovima vrtića i konkretnim situacijama učenja i 3) kognitivno-razvojni PP - zasnovani na kognitivno-razvojnim ciljevima i opširnim uputstvima kako da se organizuje sredina i predstave sadržaji, ne ograničavaju dete i vaspitača, a akcenat je na razvoju osnovnih funkcija, a ne specifičnih veština (Kamenov, 2008).

$\mathrm{Na}$ osnovu nivoa isplaniranosti aktivnosti i ponašanja deteta razlikuju se: 1) visoko strukturirani PP, u kojima su date aktivnosti dece i vaspitača i nema većih razlika u radu vaspitača i aktivnosti između različitih grupa dece; 2) PP sa niskim stepenom strukturiranosti, koji su nepredvidivi jer u njima nema propisanih aktivnosti za decu i vaspitača; 3) PP srednje strukturiranosti, u kojima su vrlo široko postavljene smernice za organizaciju aktivnosti vaspitača i dece (Pešić, 1987, prema Klemenović, 2009).

„Godine uzleta”, koje su utvrđene 2018. godine, pripadaju kognitivnorazvojnim i srednje strukturiranim programima jer se u njima navodi koji su teorijsko-vrednosni postulati, ciljevi (opšti, usmereni na dete i dugoročni), kako da dete uči i razvija se, šta sve oblikuje realni program i koji su principi i strategije razvoja realnog programa (planiranje, zajedničko razvijanje programa, praćenje, vrednovanje, dokumentovanje). Nema sadržaja aktivnosti za decu i vaspitača, metoda i oblika rada, sredstava, vremena realizacije.

Sociokulturna teorija ističe značaj zajedničkih aktivnosti za učenje i razvoj. Kroz socijalne interakcije deca uče o kulturi i kulturnim oruđima (govor, simboli, predmeti), kao i o raznim strategijama u građenju značenja, u porodici i zajednici u kojoj žive. U situacijama učenja kroz odnose svaki pojedinac svojim iskustvom doprinosi razumevanju kokonstrukcije znanja u odnosima u kojima se prepliće lično i društveno (Godine uzleta, 2019). Deca u saradnji sa iskusnijim partnerima konstruišu znanja i umenja, a stupajući u interakciju sa vršnjacima, osamostaljuju se i razvijaju trajne socijalne veštine. Na učenje utiče sadržaj onoga što se uči, kao i socijalni kontekst, a kognitivni i socijalni razvoj su povezani (kognitivni razvoj je socijalan, a socijalni kognitivan jer sadrži psihološke procese) (Pešikan i Antić, 2012).

Dete sa smetnjama u razvoju je jedinstveno, celovito, socijalno i kreativno biće, sposobno i bogato potencijalima, aktivni učesnik u društvenim odnosima zajednice vršnjaka i odraslih, sa unutrašnjom motivacijom za učenje i biće je igre. Vrtić je prostor zajedničkog življenja, mesto realnog vaspitno-obrazovnog programa, mesto poštovanja jednakosti, različitosti i refleksivne prakse, u kome se uvažavaju interesi dece, roditelja i zajednice (Godine uzleta, 2019). Praksa vrtića je promenljiva, nepredvidiva, problemska, dinamična i zahteva stalno promišljanje o vrednostima i ostvarenosti inkluzivnog obrazovanja. Predškolska ustanova je obrazovna i društvena institucija u kojoj se uvažavaju interesi dece, roditelja i zajednice. To je prostor u kome se deca i odrasli razvijaju i uče (Pavlović Breneselović i Krnjaja, 2014).

Inkluzija je pojam koji znači uključivanje (lat. inclusio), a u kontekstu obrazovanja odnosi se na uključivanje sve dece u redovan sistem obrazovanja, bez obzira na sposobnosti, zdravstveno stanje, etničku pripadnost ili bilo koju drugu ličnu 
karakteristiku. Inkluzija je pristup obrazovanju zasnovan na prilagođavanju obrazovnih institucija sa ciljem da svako dete stekne kvalitetno obrazovanje. Inkluzivno obrazovanje je odnos prema deci i način realizacije vaspitno-obrazovnog rada. Otklanjanjem institucionalnih, fizičkih i komunikacionih prepreka omogućava se deci sa smetnjama u razvoju i invaliditetom da ostvare pravo na obrazovanje, koje treba da bude jednako i dostupno za sve. To se odnosi na svako lice koje ima smetnje u razvoju ili invaliditet - telesni, čulni, intelektualni, motorički, višestruke smetnje ili smetnje iz spektra autizma (Macura, 2015).

Cilj „Godina uzleta” je podrška dobrobiti deteta. Dobrobit je sposobnost ličnog i socijalnog funkcionisanja i posedovanje potencijala za razvoj i napredak, a sagledava se kroz personalnu (oseća se dobro i uspešno funkcioniše), delatnu (ume i hoće) i socijalnu (prihvata, pripada, učestvuje) dimenziju, koje su međusobno povezane (Godine uzleta, 2019). Dobrobiti inkluzivnog obrazovanja su višestruke: osećanje prihvaćenosti i samopoštovanja, viša obrazovna postignuća, jače samopouzdanje, brojniji socijalni kontakti, brojnija prijateljstva, aktivnije provođenje slobodnog vremena, viši nivo empatije kod tipične dece i tolerantnije društvo (Macura, 2015).

\section{Podrška dobrobiti deteta kroz odnose i delanje}

Dete se razvija i uči kroz odnose, odnosno akcije i interakcije sa socijalnom i fizičkom sredinom i delanje u igri, životno-praktičnim situacijama i planiranim situacijama učenja.

Za dete sa smetnjama u razvoju, kao i za svako drugo dete, važno je da dok stupa u odnose i dela, oseća da je zaštićeno od fizičkog i psihološkog povređivanja (ponižavanja, etiketiranja, potcenjivanja), da mu se obezbedi da stalno učestvuje u igrama i situacijama učenja kroz materijale i da bude aktivno uključeno u sva dešavanja u skladu sa svojim mogućnostima (Godine uzleta, 2019). Vaspitač gradi odnose tako što prepoznaje dečje potrebe, osećanja, interesovanja i kapacitete, te mu u skladu sa tim pruža podršku, pri čemu planiranjem, organizacijom i postupcima održava ravnotežu između zavisnosti deteta sa smetnjama u razvoju od odraslog i samostalnosti (Pavlović Breneselović i Krnjaja, 2017). Da bi dete sa smetnjama u razvoju zaista učestvovalo u situacijama učenja, treba uneti neke izmene u skladu sa detetovim potrebama, npr. obmotavanje bojice kanapom kako bi bile većeg prečnika, sedenje bliže osobi koja govori, primena slika sa jarkim i kontrastnim bojama (Moran, 2014).

Dete u igri doživljava sebe kao deo grupe i zajednice, ispituje i prevazilazi stereotipe, prihvata pravila, istražuje i (re)konstruiše značenje - istražuje, imitira i stvara nove reči (Godine uzleta, 2019). Vaspitač podržava igru kao partner u igri predstavljajući određeni model ponašanja, koristi različita sredstva, materijale ili pomagala (npr. kalendar dnevnih i nedeljnih aktivnosti, vizuelni merač vremena, računaljku, podmetač za stolicu, plastelin, testeninu, pesak, ručno izrađena sredstva po uzoru na Montesori pedagogiju), s ciljem da zainteresuje i uključi dete sa smetnjama u igre i planirane situacije učenja, a u skladu sa njihovim izražavanjem, menja materijale, fizičko i socijalno okruženje (Pavlović Breneselović i Krnjaja, 2017). 
U skladu sa svojim mogućnostima, dete u životno-praktičnim situacijama gradi odnose kroz obavljanje zajedničkih poslova i obaveza, razvija samostalnost, opušteno je i odmara se (Godine uzleta, 2019). Vaspitač koristi obedovanje, rođendanske proslave i dr. kao situacije prijatnog druženja; omogućava deci sa smetnjama u razvoju učešće u događajima u lokalnoj zajednici, gde će učiti o svetu oko sebe kroz uloge i odnose; podstiče saradničko ponašanje razvijajući kulturu pomaganja onima kojima je pomoć potrebna i podstiče decu da samostalno smišljaju rituale koji će obogaćivati život grupe (Pavlović Breneselović i Krnjaja, 2017). Odstupanja od rutina dete sa smetnjama u razvoju zbunjuju i uznemiruju, dok njihova ustaljenost povećava samostalnost u funkcionisanju (Mrše i Jerotijević, 2012).

Vršnjaci pružaju podršku i pomoć drugarima kojima je to potrebno, razvijajući empatiju, dok se kod dece sa smetnjama stvara osećaj pripadanja i prihvaćenosti. S druge strane, vaspitač neguje grupni identitet kroz zajedničke rituale kao što su proslave rođendana ili jutarnje okupljanje na tepihu, u kojima dete sa smetnjama stupa u odnose sa drugima, raduje se i oseća da pripada grupi; ličnim modelom podstiče decu da ne koriste nepoželjne oblike ponašanja (etiketiranje, omalovažavanje, ignorisanje, tužakanje); podstiče decu da pomažu jedni drugima u igri i životnim situacijama; uvažava različitosti i pomaže deci da ih uvažavaju; organizuje prostor, vreme i materijale za aktivnosti u paru ili malim grupama (Godine uzleta, 2019).

Od prvog dana roditelji treba da se osećaju prijatno u vrtiću, što se postiže putem postera dobrodošlice, sobe za razgovor i sl. Roditelji su partneri u kreiranju strategija razvoja realnog programa (Godine uzleta, 2019) i podstiču se da prate decu prilikom adaptacije nekoliko dana, da rade kao volonteri, te da dođu u posetu kada požele (Moran, 2014). Oni se pitaju šta je važno za njihovo dete, šta bi voleli u odnosu na svoje dete i sebe, koje su detetove jake strane, interesovanja i šta voli, jer oni najbolje poznaju svoje dete. Roditelji se pozivaju da učestvuju u planiranim situacijama učenja, organizuju se druženja sa porodicama, svakodnevno se sarađuje sa roditeljima iz različitih razloga.

\section{Kontekst realnog programa}

Program se razvija u realnom kontekstu vrtića i oblikuje ga kultura vrtića, porodice i društvene zajednice. Inkluzivna praksa se razvija pod uticajem mišljenja svih zaposlenih u vrtiću i predškolskoj ustanovi, roditelja i šire zajednice, njihovih stavova prema deci sa smetnjama u razvoju, netolerancije na različitosti, te mišljenja o uključivanju dece sa smetnjama u redovne grupe (Macura, 2015). Broj dece u grupi i struktura grupe utiču na kvalitet odnosa između dece sa smetnjama i vaspitača, kao i na mogućnosti njegovog učešća u igri i u situacijama učenja (Godine uzleta, 2019).

Vaspitač je kroz neposredni rad u grupi usmeren na dobrobit deteta kroz odnose, delanje i zajedničko učešće. On planira i razvija program zajedno sa drugim učesnicima i prati, dokumentuje i vrednuje razvoj realnog programa kroz inkluzivno obrazovanje (sredina za učenje, prihvatanje različitosti, učešće, kvalitet odnosa). Vaspitači se profesionalno osnažuju za inkluzivnu praksu kroz stalno 
usavršavanje putem stručne literature i seminara, saradnjom sa kolegama i stručnim saradnicima, te povezivanjem sa kolegama iz drugih ustanova radi razmene iskustava. U profesionalnom javnom delovanju vaspitač zastupa interese dece sa smetnjama u razvoju i njihovih porodica, ukazuje na probleme u praksi prilikom uključivanja dece sa smetnjama u razvoju u predškolske ustanove, a svakodnevne aktivnosti su u skladu sa profesionalnim delovanjem i etičkim pravilima (Godine uzleta, 2019). Prilikom povezivanja sa zajednicom, vaspitač uključuje dete sa smetnjama u razvoju u sve aktivnosti van prostora vrtića (pekaru, pijacu, park, muzej, pozorište, sportski klub), nastoji da inkluzivna praksa postane vidljiva kako spolja (putem fotografija ili crteža), tako i unutra (organizovanjem otvorenih vrata) (Vandekerckhove i dr., 2013).

Prostor se organizuje tako da omogućava saradnju i pozitivnu međuzavisnost, uvažava inicijativu, posvećenost, istraživanje, stvaralaštvo, eksperimentisanje, različitost, senzorni, estetski osećaj i začudnost, a nameštaj je udoban i funkcionalan (Godine uzleta, 2019). Prostor kao neposredna sredina za učenje treba da sadrži materijale koji će angažovati više čula istovremeno (materijale različitih oblika, tekstura, boja, muziku, zvučne elemente), sa jasno obeleženim vizuelnim oznakama prostora jarkim bojama u kontrastu i materijalima različite teksture (Mrše i Jerotijević, 2012). U radnoj sobi treba da postoji prostor sa mekim delovima, jastucima, knjigama i materijalima za mirnije aktivnosti, koji je udaljen od bučnih prostornih celina, gde dete sa smetnjama u razvoju može da se povuče i odmori kada mu je potrebno (Moran, 2014).

Fizička sredina treba da bude u skladu sa ciljevima univerzalnog dizajna - s telesnom adekvatnošću, udobnošću, svesnošću, dobrobiti, socijalnim uključivanjem i personalizacijom (Toping, 2014), kojima se uzimaju u obzir različitosti svakog deteta u vrtiću s ciljem podržavanja dobrobiti deteta sa smetnjama u razvoju. Organizacijom prostora daje se mogućnost detetu sa smetnjama u razvoju da u skladu sa svojim mogućnostima otkriva načine učestvovanja u zajedničkim istraživanjima, uživa u interakciji sa drugima i raduje se ostvarenjima i vlastitom doprinosu (Godine uzleta, 2019). Vaspitač je usmeren na učenje svakog deteta, posebno osmišljava načine na koje će podržati učešće dece sa smetnjama u razvoju (individualizacija), omogućuje deci izbore kroz različita sredstva i materijale i razvija uzajamnu podršku kroz prihvatanje, uvažavanje i isticanje vrednosti zajedničkog doprinosa (Pavlović Breneselović i Krnjaja, 2017).

\section{Strategije vaspitača u razvijanju realnog programa}

Strategije, kao jasni planovi ostvarenja razvoja realnog programa, planiranje, zajedničko razvijanje programa i praćenje i vrednovanje putem dokumentovanja razvijaju se u skladu sa principima usmerenosti na odnose, životnosti, integrisanosti, autentičnosti, angažovanosti i partnerstva (Godine uzleta, 2019). Planira se samo nekoliko koraka unapred, na sledeći način:

- Polazeći od principa „Godina uzleta”, vaspitači planiraju promene u fizičkoj sredini koje će omogućiti detetu sa smetnjama da stupa u odnose, bude angažovano i stiče integrisana iskustva.

- Vaspitač planira kada će se i kojim medijima (razgovorom, pitanjima i od- 
govorima, fotografijama, crtežima) upoznati sa prethodnim iskustvima, znanjima i doživljajima dece sa smetnjama u razvoju koji su u vezi s projektom.

- Deca razgovaraju u porodici o projektu, a vaspitač razgovara sa roditeljima kako bi saznao koja interesovanja i iskustva dete sa smetnjama poseduje o projektu i koje su njegove jake strane na koje se treba osloniti kako bi se istakao njegov doprinos prilikom učešća u igrama i planiranim situacijama.

- Planiranje je fleksibilno, što omogućuje promene i dopune prema mogućnostima, željama i potrebama dece, i dokumentuje se (Pavlović Breneselović i Krnjaja, 2017).

U razvijanju realnog programa vaspitaču su partneri deca, roditelji, kolege i drugi profesionalci i članovi lokalne zajednice (Godine uleta, 2019).

- Deca preuzimaju inicijativu pri izboru aktivnosti i materijala kojima će se baviti, a vaspitač različitim medijima istražuje kako bi deca želela da izgleda prostor (Godine uzleta, 2019). Razgovara se, postavljaju se pitanja, listaju se slikovnice sa detetom, analiziraju se crteži i fotografije prostora u kom dete sa smetnjama voli ili ne voli da se igra. Kroz razgovor o provedenom danu od dece saznajemo šta možemo promeniti u prostoru kako bismo smanjili ili uklonili komunikacijske i fizičke prepreke za uključivanje deteta sa smetnjama u razvoju.

- Roditelji svojim idejama, predlozima i učešćem doprinose uključivanju i održavanju kontinuiteta $\mathrm{u}$ iskustvima deteta sa smetnjama u razvoju (Godine uzleta, 2019). Vaspitači podstiču učešće roditelja u razvijanju programa, prihvataju njihove ideje, pozivaju roditelje da borave u vrtiću i zajedno kreiraju situacije učenja.

- Kolege i drugi profesionalci idejama i predlozima podstiču preispitivanje vaspitača o realizaciji programa i njegovoj pristupačnosti svakom pojedincu (Godine uzleta, 2019). Vaspitači kontaktiraju stručnjake koji rade sa detetom sa smetnjama u razvoju ili stručnjake iz lokalne zajednice, vodeći računa o zaštiti podataka o ličnosti, i razgovaraju o načinima na koje dete uči, koje će primeniti prilikom individualizacije. Razgovarajući sa kolegama, razmenjuju se ideje i iskustva, što pozitivno utiče na razvoj inkluzivne prakse.

- Uključivanje članova lokalne zajednice (stručnjaka i volontera) u zajedničku igru i istraživanje, koji će davati svoje predloge o unapređivanju inkluzivnog obrazovanja dece sa smetnjama u razvoju (Godine uzleta, 2019). Vaspitači podstiču učešće članova zajednice koji imaju određene talente, na primer za muziku ili tradicionalne zanate, da dođu da rade sa decom (Moran, 2014).

Praćenje, dokumentovanje i vrednovanje realnog programa rada sa decom predškolskog uzrasta sa smetnjama u razvoju odvija se kroz individualni i projektni portfolio. Dečji individualni portfolio sadrži priče za učenje, produkte nastale u projektu (video i audio zapise, crteže), skale procene uključenosti deteta, podršku njegovoj dobrobiti, beleške vaspitača, roditelja i raznih stručnjaka. Projektni portfolio sadrži podatke o tome kako su deca sarađivala, kako uvažavaju različitosti, podatke o načinu učešća roditelja, individualnom interesovanju dece, te o tome šta se radilo, kako i čime (fotografije, snimci, procesni panoi). Praćenje i vrednovanje se odvija različitim tehnikama (posmatranjem, analizom sadržaja, skaliranjem, sociometrijom) i instrumentima (skalama procena, beleškama, listama, sociogramima). Procena dobrobiti i uključenosti deteta sa smetnjama u ra- 
zvoju vrši se na osnovu atmosfere u grupi. U dokumentovanju i vrednovanju učestvuju deca, vaspitači, roditelji i stručni saradnici (Krnjaja i Breneselovic, 2017).

Pedagoški profil sastavljaju vaspitač, roditelj i stručni saradnik, a sadrži opis obrazovne situacije deteta sa smetnjama u razvoju i predstavlja osnovu za planiranje mera individualizacije. Ako oni procene da mere individualizacije ne dovode do očekivanog ishoda, onda se pristupa izradi individualnog obrazovnog plana (u daljem tekstu IOP). IOP se piše za jedno dete, za njegovu obrazovnu situaciju, proističe iz njegovog pedagoškog profila uz saglasnost roditelja, a sastavlja ga tim za pružanje dodatne podrške detetu (u daljem tekstu tim). U sastavu tima su vaspitač, roditelj, stručni saradnik, saradnik u predškolskoj ustanovi, a po potrebi deteta i pedagoški asistent i lični pratilac, stručnjak van ustanove na predlog roditelja. U pisanju, realizaciji i vrednovanju IOP-a učestvuju svi članovi tima. IOP se vrednuje u prvoj godini tromesečno, a u narednim radnim godinama na šest meseci. Na osnovu vrednovanja, uz saglasnost tima za inkluzivno obrazovanje, koji čine stručni saradnik, dva vaspitača i dva saradnika, pedagoški kolegijum donosi odluku o promeni, dopuni i izmeni IOP-a. Evidencija o sprovođenju i vrednovanju IOP-a vodi se u propisanoj formi, a dokumentacija koja ga prati je sastavni deo pedagoške dokumentacije koju vodi predškolska ustanova (Pravilnik o bližim uputstvima za utvrđivanje prava na individualni obrazovni plan, njegovu primenu i vrednovanje, 2018). Ako su za ostvarivanje mera individualizacije potrebna finansijska sredstva, ustanova i roditelji mogu podneti zahtev interresornoj komisiji za njihovo odobrenje (Pravilnik o dodatnoj obrazovnoj, zdravstvenoj i socijalnoj podršci detetu, učeniku i odraslom, 2018).

\section{Zaključak}

„Godine uzleta” su nacionalni okvir predškolskog vaspitanja i obrazovanja Republike Srbije i sadrže elemente savremenih kurikuluma i programa sa široko datim smernicama za realizaciju vaspitno-obrazovnog rada.

Teorijsko-vrednosni postulati vide u detetu sa smetnjama u razvoju potencijale, vrtić kao zajednicu učenja, a predškolsku ustanovu kao mesto osposobljavanja za uspešan lični i društveni život. Uklanjanjem komunikacionih i fizičkih prepreka, uređenjem prostora po ciljevima univerzalnog dizajna, te upotrebom materijala i pomagala povećava se samostalnost u funkcionisanju i mogućnost stupanja u odnose i delanje deteta sa smetnjama u razvoju u igri, životno-praktičnim i planiranim situacijama učenja. Rutine i rituali daju im osećaj sigurnosti i pripadnosti, a kod ostalih učenika stvara prijatna osećanja zajedničkog življenja.

Inkluzivno obrazovanje se razvija pod uticajem kulture i strukture vrtića, uže i šire društvene zajednice. Vaspitači stalnim usavršavanjem i profesionalnim javnim delovanjem utiču na promenu konteksta u kome se razvija inkluzivna praksa tako što menjaju odnos zajednice življenja prema deci sa smetnjama u razvoju.

Polazeći od principa "Godina uzleta”, fleksibilno se planiraju i dokumentuju prilagođavanje fizičke sredine i vrste medija kojim će se saznati iskustva deteta sa smetnjama o projektu. Inkluzivnu praksu razvijaju zajedno deca sa smetnjama, vršnjaci, vaspitači, porodica i članovi lokalne zajednice. Fleksibilnost početnog planiranja omogućava prilagođavanje interesovanjima i potrebama dece sa smetnjama u razvoju. 
Individualizacija podrazumeva prilagođavanje potrebama dece sa smetnjama u razvoju kako bi ona bolje učila, bila samostalnija i bila jednostavno uključena $\mathrm{u}$ život i rad grupe. Ukoliko mere individualizacije ne daju rezultate, onda se pristupa pisanju IOP-a. IOP je zvanični dokument ustanove, kojim se planira dodatna podrška, ako prethodna prilagođavanja nisu dovela do ostvarivanja opštih ishoda obrazovanja i vaspitanja. Za decu predškolskog uzrasta nije preporučljivo žuriti sa pisanjem IOP-a, već je potrebno izraditi detaljan plan prilagođavanja, pedagoški profil koji je sastavni deo dokumentacije IOP-a. Dobra inkluzivna praksa je ona koja se zasniva na principima „Godina uzleta”, pružajući podršku dobrobiti deteta sa smetnjama u razvoju i invaliditetom kroz ono što jeste u ono što će biti u budućnosti. 
INKLUZIVNO OBRAZOVANJE DECE PREDŠKOLSKOG UZRASTA SA SMETNJAMA U RAZVOJU PO „GODINAMA UZLETA”

\section{Literatura}

Kamenov, E.(2008). Obrazovanje predškolske dece. Beograd: Zavod za udžbenike. Klemenović, J. (2009). Savremeni predškolski programi. Novi Sad - Vršac: Savez pedagoškog društva Vojvodine - Visoka škola strukovnih studija za obrazovanje vaspitača „Mihailo Palov”.

Krnjaja, Ž. i Pavlović Breneselović, D. (2017). Kaleidoskop - Projektni pristup učenju. Beograd: Institut za pedagogiju i andragogiju, Filozofski fakultet Univerziteta u Beogradu.

Macura, S. (2015). Inkluzivno obrazovanje: kvalitetno obrazovanje za sve. Jagodina: Fakultet pedagoških nauka Univerziteta u Kragujevcu.

Moran, M. (2014). Inkluzivno predškolsko vaspitanje i obrazovanje, stručni priručnik (Vebiner 9). UNICEF.

Mrše, S. i Jerotijević, M. (2012). Priručnik za pisanje individualnog obrazovnog plana, neredigovana verzija. Beograd: Ministarstvo prosvete, nauke i tehnološkog razvoja. file:///D:/kurikulumi/Prirucnik_za_planiranje_i_pisanje_IOP.pdf

Osnove programa predškolskog vaspitanja i obrazovanja - Godine uzleta (2019). Beograd: Ministarstvo prosvete, nauke i tehnološkog razvoja.

Pavlović Breneselović, D. i Krnjaja, Ž. (2014). Osnove programa kao dimenzije kvaliteta predškolskog vaspitanja i obrazovanja. Pedagogija, 69(2), 212-225. Preuzeto sa http://www.forumpedagoga.rs/wp-content/uploads/2018/07/Pedagogija-br.-2-za-2014..pdf

Pavlović Breneselović, D. i Krnjaja, Ž. (2017). Kaleidoskop - Osnove diversifikovanih programa predškolskog vaspitanja i obrazovanja. Beograd: Institut za pedagogiju i andragogiju, Filozofski fakultet Univerziteta u Beogradu.

Pravilnik o bližim uputstvima za utvrđivanje prava na individualni obrazovni plan, njegovu primenu i vrednovanje (2018): Službeni glasnik RS, br. 88/17 i 27/17.

Pravilnik o dodatnoj obrazovnoj, zdravstvenoj i socijalnoj podršci detetu, učeniku $i$ odraslom (2017, 2018). Službeni glasnik RS, br. 88/17 i 27/18.

Pešikan, A. i Antić, S. (2012). Učenje i razvoj na ranim uzrastima. U: A. Baucal (ur.), Standardi za razvoj i učenje dece ranih uzrasta u Srbiji (85-111). Beograd: Institut za psihologiju Filozofskog fakulteta.

Toping, B. (2014). Pristup školi i obrazovno okruženje I - fizički aspekt, informisanje i komunikacija, stručni priručnik (Vebiner 10). UNICEF. https://www. unicef.org/eca/sites/unicef.org.eca/files/Booklet\%2010\%20-\%20Serbian\%20 Version_0.pdf

Vandekerckhove, A., Trikić, Z., Miškeljin, L., Peeters, J., Lakićević, O. i Koruga, D. (2013). Priručnik za diversifikaciju programa predškolskog vaspitanja i obrazovanja. Beograd: Ministarstvo prosvete, nauke i tehnološkog razvoja Republike Srbije. 
Ivana Tasić, Slađana Raspopović

Ivana Tasić

"11. April“ Preschool, Novi Beograd

Sladjana Raspopović

"Poletarac" Preschool, Batočina

\title{
INCLUSIVE EDUCATION OF PRESCHOOL CHILDREN WITH DEVELOPMENTAL DISABILITIES ACCORDING TO "YEARS OF ASCENT“
}

\begin{abstract}
The basis of preschool education programme "Years of Ascent" is established according to the structural elements and requirements of modern curricula. The theoretical-value concept determining its goal is then considered regarding children with disabilities. It is analysed how to support the well-being of children with developmental disabilities through relationships and activities in play, real life situations and planned learning situations, as well as in relation to the context of kindergarten where inclusive practice is implemented. Teachers' work, organization of physical space, strategies (principles, initial planning, joint programme development, monitoring, evaluation and documentation) are discussed in relation to inclusive practice. There are instructions on exercising the legal right to IEP, its realization and evaluation.
\end{abstract}

Key words: inclusive practice, child with disabilities, "Years of Ascent". 